\title{
Editorial
}

Heartiest Eid Mubarak to all our readers, authors and well wishers! This issue of the Bangladesh Journal of Bioethics has a unique combination of papers focusing on rights - human and animal. The papers search deeply into the ethical issues related to scientific research and raises pertinent questions. Another critical topic addressed is the mutually beneficial relationship between the pharmaceutical industry and the physicians and possible impact on the services to patient. All the papers are important and highly relevant to the principles of Bioethics.

Shahinul Alam, et al in their paper on the Ethical Relation between Physicians and Pharmaceutical Industries in the Perspectives of Bangladesh, have reviewed guidelines in different countries on gifts provided to physicians , cash back, samples, industry sponsored scientific meetings, research and hospitality by the pharmaceutical industry. The authors conclude that Bangladesh is lagging behind in protecting the patient's rights properly with regard to update regulations, adherence to existing guidelines and lack of guidance from statutory bodies. The current situation in Bangladesh does not address the rights of the patients and needs attention from both professionals and pharmaceutical associations.

Dr. Nahid Ferdousi examines the ethical issue of using Children as Research Subjects. The study explores some of the major ethical issues that arise in research involving children during and after the research in terms of the best interests of the children. The paper is particularly important not only in terms of research ethics but also whether the UN Convention on the Rights of the Child and the International Covenant on Civil and Political Rights has been respected or transgressed.

Zoheb Rafique in his paper on Animal Rights and Use of Animals in Biomedical Research discusses in detail that how animals should be handled while doing research and what are animal rights and their uses in biomedical research.

Ali Jamkarani expresses the thought of the human rights in Shiite perspective in his article entitled Human Rights: Illusion or Reality; Theological (Shiite) Perspective. This article has two parts. Part 1 of this article publishes in this issue. Part 2 of this article including conclusion and full bibliography will be published in BJB 2015; Vol 6 Issue 2.

Norman K. Swazo in his comments on CRISPR/Cas9-mediated Editing of Human $\beta$-globin Gene in Human Cells discusses the recent Chinese research using a gene-editing technology on abnormal human zygotes. This research has prospective clinical application. This paper reviews the ethical issues of the research report and come to the conclusion that the Chinese research team did not meet the standards of scientific responsibility.

Jaime A. Teixeira da Silva in his commentary on Pay walled retraction notices questions the morality of whether a COPE (Committee on Publication Ethics) member should be charging money for access to retraction notices. The author queries whether this would this not be a direct violation of COPE's code of conduct. A retraction of a scientific paper is made, most often due to errors or lack of publishing ethics on the part of authors, or, on occasion, duplicate publication by a publisher in error. The retraction notice that accompanies the retraction is important document that 
provides a background to the public regarding the reason why the manuscript was retracted. As several journals and publishers, some of which are COPE members, are selling the retraction, the author questions the ethical side of it.

Dear Readers,

As we all know, to make the world more livable and more rights based, the importance of Bioethics cannot be over emphasised. This interesting and relevant field of ethics and ethical rights encompasses a huge, comprehensive arena from robotics and genetics to exploring the universe. Let us all, through this journal, strive towards greater equality and equity. Looking forward to your papers.

\section{Best Regards}

\section{Tahera Ahmed}

Former Chief, Sexual and Reproductive Health, UNFPA,

Faculty, North South University,

And

Editor, Bangladesh Journal of Bioethics 